\title{
MINIMIZING COMMUNICATION RISK IN CONSTRUCTION: A DELPHI STUDY OF THE KEY ROLE OF PROJECT MANAGERS
}

\author{
Anita CERIC \\ Faculty of Civil Engineering, University of Zagreb, Kaciceva 26, 10000 Zagreb, Croatia
}

Received 08 Feb 2012; accepted 12 Nov 2012

\begin{abstract}
All significant construction projects involve the project owner and the contractor, as well as their project managers. Following upon recent research into the multiple principal-agent problem, which was applied to the minimization of communication risk in construction projects, the focus here is on communication issues between the four project parties. Recent research has shown that the relationship between the project owner and the contractor is paramount for risk minimization before the contract between them is signed. However, the relationship between project managers is dominant for risk minimization after the contract is signed. To further explore risk minimization at this stage of the project, the Delphi method was employed. A panel of highly-experienced project managers working for both project owners and contractors was asked several rounds of questions in an attempt to arrive to a consensus concerning the most important relationships between project parties in terms of risk minimization after the contract is signed. The relationship between the two project managers tops the ranking, thus focusing further research. As they are both agents, and as there is no contract between them, this offers a fresh challenge for the principal-agent theory.
\end{abstract}

Keywords: principal-agent theory, communication risk, construction projects, project management, Delphi method.

\section{Introduction}

Good communication between key participants is essential for the success of every construction project (Zavadskas et al. 2010). Poor communication is one of the most common project risks (Ceric 2003). Communication involves sharing relevant information between project participants. It is commonly assumed that all participants cooperate and exchange information in order to achieve project's goals. However, there is a potential conflict of interests between project participants because they all have their own interests, as well (Park et al. 2010).

The situation in which one of the two parties is better informed than the other is well known in economics as the principal-agent problem (e.g. Jäger 2008). The principal-agent problem deals with the design of contract with respect to asymmetric information (Huang, Hsueh 2010). In construction projects, the project owner and contractor as principal and agent form the key relationship (Turner, Müller 2004). Delegation of tasks establishes a principal-agent relationship between the project owner and manager, where the principal (project owner) depends on the agent (contractor or project manager) to undertake a task on the principal's behalf (Müller, Turner 2005). One can act on assumption that an agent will try to maximize his or her own benefit even when that may involve a higher damage to the client (Schieg 2008).
According to the principal-agent theory, this problem is characterized by three issues concerning the relationship between the principal and the agent: adverse selection, moral hazard, and hold-up. These three issues will be discussed in the next section.

The literature review shows that the application of the principal-agent problem in construction is extensive. It covers all three issues of risk concerning the relationship between the principal and agent: adverse selection, moral hazard, and hold-up. Analyzing papers that have been published so far, it can be concluded that most authors have researched moral hazard dealing with supply chain management, procurement systems, make-or-buy decisions, and outsourcing (Rosenfeld, Geltner 1991; Tadelis 2002; Yiu et al. 2002; Ive, Chang 2007). Some authors have discussed the adverse selection problem and its impact on building performance and building quality (Holt et al. 1995; Corvellec, Macheridis 2010). It should be noted that the hold-up problem dealing with subcontracting and procurement systems has attracted least attention so far (Chang, Ive 2007; Unsal, Taylor 2010). However, the literature does not cover the relationship between project managers in construction projects, which is at the core of the research presented in this paper.

The research presented here was conducted in two phases. In the first phase, an exploratory survey of

Corresponding author: Anita Ceric

E-mail: anita@grad.hr 
project managers with considerable experience was used to establish the relative importance of communication risk sources and types of relationship in construction projects. Since this research is exploratory in nature, a questionnaire survey was considered an appropriate tool. The objective was to establish an understanding of the relative importance of a number of communication risks established in the literature. The respondents were project managers with considerable experience and expertise in the field. They were selected for this study because they play central roles in all construction projects. Their perceptions of communication risks are thus important. However, the survey respondents cannot be said to be representative of all project managers, the population of which is beyond the scope of this paper.

Out of thirty-five construction project managers approached, twenty-seven participated in the survey (response rate: 75 percent). Several of them were involved in an initial pilot survey to ensure its comprehensibility. On the average, the respondents had fifteen years of experience on a wide variety of construction projects. The largest projects they had managed had an average value of $\$ 1$ billion. Many of the largest projects were in infrastructure, but all other types of projects were represented. Collectively, the respondents worked on construction projects in a wide range of countries on most continents. The respondents were asked to offer their perceptions, and they felt comfortable expressing them. The survey took two weeks.

The focus was placed on project managers because they are most intimate with the construction process itself. It was found that the relationship between the project owner and contractor is the most important before the contract is signed between them. It should be pointed out that this finding suggests that there was no bias among the respondents. It was also found that, after the contract is signed between the project owner and contractor, the most important relationship for risk minimization in the process of monitoring is that between the project owner's and contractor's project managers.

In the second phase, the Delphi method was used to investigate this important finding in greater detail. This method can be valuable for developing theory (Okoli, Pawlowski 2004). The focus was placed on the monitoring process itself, which is central to risk minimization during construction.

In the pages that follow, asymmetric information and communication risk are first introduced. Next, the principal-agent theory framework in construction projects is presented. Special emphasis is placed on the communication risk in connection with asymmetric information. Then the research method is discussed. The results of the Delphi survey are presented in two sections: first, the respondents' perceptions of risk minimization are discussed; second, the main findings are presented. Then the limitations of the study are briefly discussed. The paper closes with conclusions including ideas for future research.

\section{Asymmetric information and communication risk}

There is a large literature on asymmetric information and its applications. Only a few sources will be used in this section for explanatory purposes. In particular, the presentation relies on Jäger (2008) and Schieg (2008).

Asymmetric information occurs whenever the principal and the agent are not in possession of the same information at the same time. In construction projects, there are four key parties who work together: the project owner, the contractor, and their project managers. It is customarily assumed that they will share important information in order to meet the main project targets: time, cost, and quality. However, because of self-interest, the four parties will not be willing to share all the information all of the time. The following types of information asymmetry apply in cases like this one: hidden characteristics, hidden information, and hidden intention. Respectively, these three types of information asymmetry generate the following risks: adverse selection, moral hazard, and hold-up.

Adverse selection describes information asymmetries when the principal does not have the exact qualifications of the agent. It occurs before the contract is signed and the result can be the wrong choice of the contractual partner. In the case of moral hazard there are information asymmetries after the contract is signed. The principal cannot control all the agent's activities and an information imbalance in favour of the agent can thus occur. If the agent uses this situation opportunistically, then this type of asymmetric information is called moral hazard. If the principal makes large investments in money or other resources because of the trusty relationship with the agent, and if these investments come into jeopardy in the case the agent acts uncooperatively, the resulting problem is called hold-up. The principal has already made an irreversible investment and this enables the agent to confront him with excessive demands, for instance.

\subsection{Construction projects}

Based on the principal-agent theory, the relationships between the project owner, the contractor, and their project managers are systemized according to the related types of asymmetric information and the corresponding types of risk. Again, hidden characteristics are associated with adverse selection; hidden action and/or hidden information are associated with moral hazard; and hidden intentions are associated with hold-up.

Hidden characteristics cause the adverse selection problem before contracts are signed between the parties involved. The most important among them is the contract between the project owner and the contractor. Choosing the proper contractor is a complicated problem for clients (Zavadskas et al. 2010). Adverse selection means that the project owner does not have all the information about the contractor before the contractor is hired. Similarly, the project owner does not have all the information about the project manager before hiring. The same holds for 
the contractor and the project manager hired. The adverse selection problem occurs in the early phases of the project. Generally, these phases are important from the point of view of risk. The early phases of a project are of particular interest because the level of influence on total project costs is highest early on; also, the impact of early decisions on total project costs is the highest (Hendrickson, $\mathrm{Au}$ 1989). The potential influence of stake-holders is also highest in the early project phases, before a detailed agenda is set and the cost for making changes is relatively low (Kolltveit, Grønhaug 2004).

Hidden information or hidden action causes the moral hazard risk. This occurs after contracts are signed between the parties involved. Again, the contract between the project owner and the contractor is the most important among them. Moral hazard means that the client cannot be sure that the companies, once hired, will fully mobilize their capabilities on the client's behalf or on behalf of other clients of theirs (Winch 2002). In our case, four parties are potentially involved in the moral hazard problem. After the contract is signed and the project owner has hired the contractor, as well as after the project owner and the contractor have hired their project managers, they cannot be sure that all the relevant information will be shared in an appropriate way because of their self-interest. People will not act in the interest of others, their principals or partners, to the exclusion of their own preferences (Eisenhardt 1989; Jensen 2000). The moral hazard problem also occurs between two project managers because they have their own self-interest, as well.

Hidden intentions can cause hold-up problems. The project owner can invest resources at any stage of the project in trust that the contractor will cooperate, but it can happen that the contractor will act opportunistically. Once the project owner realizes that the contractor is behaving opportunistically, it can be too late for the project owner to withdraw the resources already invested.

\subsection{Risk minimization}

There are several ways to minimize risks that arise from adverse selection, moral hazard, and hold-up problems. These are screening and monitoring. The former is relevant before the contract is signed, whereas the latter is relevant after signing. The purpose of screening is to gather information of use to the principal in an effort to learn more about the agent's qualifications - for instance, references, certificates, work probes, and credit worthiness. Similarly, the purpose of monitoring is to ascertain that the agent is behaving in accordance with the contract. As both of these are costs, they are known in the literature as "agency costs".

\section{Principal-agent theory framework for construction projects}

The owner of a project is the person or group who provides the financial resources for its delivery, accepts the project milestones, and project completion (Project
Management Institute 2009). The project owner hires a contractor to perform all the activities required to complete the project (Fig. 1).

Both the project owner and contractor in any major project are represented by their project managers, to whom many of their tasks are delegated. Together, they can be considered the four key parties to every major project (Fig. 2).

\section{Research method}

At any one time, project managers are geographically spread apart, as well as not available for consultation over lengthy periods of time. Therefore, the Delphi method was chosen as an appropriate approach to survey their opinion. The Delphi method is a method for obtaining and processing judgmental data. It consists of a sequenced program of interrogation in session or by mail (Brauers 2008, 2012). The Delphi method was introduced by the Rand Corporation in the 1950s with the objective of obtaining the most reliable consensus from a group of experts. It is especially effective in difficult areas that can benefit from subjective judgements on a collective basis (Lindeman 1975). A panel of ten to fifteen experts has proved to be a good guideline (Delbecq et al. 1975). The consensus is reached through structured communication involving feedback over several iterations (Linstone, Turoff 1975). At each iteration, each respondent can see the responses to the previous iterations of all other respondents without knowing who they are. It makes it possible for experts to change their previous assessments in the light of new information provided by their peers (Chan et al. 2001). The objective of these iterations is to achieve the desired level of consensus among panellists, for which measures of central tendency and level of dispersion are typically used to present the collective judgement of respondents (see, e.g. Hsu, Sandford 2007). The method is especially suitable when time and cost constraints make frequent face-to-face meetings difficult to arrange (Ericsson, Henricsson 2005).

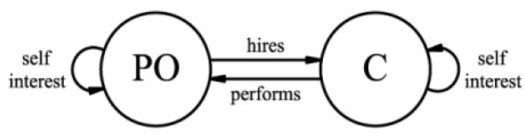

Fig. 1. Project owner-contractor relationship (PO: Project Owner, C: Contractor)

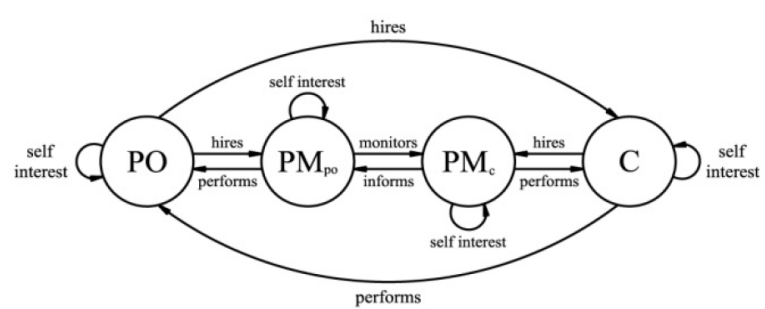

Fig. 2. Principal-agent theory framework for construction projects (PO: Project owner, C: Contractor, PMpo: Project owner's project manager, PMc: Contractor's project manager) 
One of the standard problems with the application of the Delphi method is the selection of the experts (Sharkey, Sharples 2001; Yousuf 2007; Hsu, Sandford, 2007). This is especially important when it is not possible to ascertain the degree to which the selection is representative of the population in question. In this research, three criteria were used to select the project managers for the study:

1. Level of experience as measured by the years involved in the field;

2. Size of the largest project managed in terms of its monetary value; and

3. Involvement in a variety of projects as measured by the number of countries covered.

Collectively, the respondents worked on construction projects in a wide range of countries on most continents. Among more than thirty countries, they worked in Egypt, Hong Kong, India, Iraq, Italy, Pakistan, Poland, Russia, Saudi Arabia, Spain, Switzerland, Turkey, the United Kingdom, and the United States. They can therefore be understood as experts in the field.

There were two Delphi rounds in the research reported here. For the first round, 20 respondents were selected by sharpening the above criteria for the purposes of the Delphi method. Given the focus on risk minimization in the construction phase, the project managers with greatest experience in the field were selected. All of them were practitioners with considerable expertise, as witnessed by their thirteen years of experience on the average, and the average of the largest project they managed assessed at $\$ 1.4$ billion, of which the latter was considered more important than the former. Also, they had considerable international experience. Collectively, they had worked on all continents. In the first round, 15 out of 20 selected respondents participated (response rate: 75 percent). The first round took one week.

In the second and final Delphi round, 11 out of 15 respondents took part (response rate: 73 percent). Also, 7 out of 15 respondents, or 47 percent, chose to modify their scores in view of the results of the first Delphi round. The second round took one week. Survey questions for two Delphi rounds can be found in Appendices A and B.

The scale used here is ostensibly ordinal, and ordinal data do not permit statistical analysis using means and standard deviations, but only medians and ranges instead (Stevens 1946). However, the scale used here can be meaningfully interpreted as the interval scale, as it involves only levels of importance, from least to most important. Each level of importance can be interpreted as the same as any other, and the scale can thus be interpreted as linear. In such a case, especially if the scale is sufficiently wide, it is permissible to treat the ordinal scale as an interval one (Knapp 1990). Therefore, means and standard deviations can be used in the statistical analysis applied to the interpretation of the data.

Given that one of the fundamental goals of the Delphi method is the achievement of a satisfactory consensus between panel experts, it is necessary to conduct a quantitative analysis of the consensus by means of a nonparametric statistical test.

One of the metrics that is widely recognized as the best is Kendall's coefficient of concordance, W (Okoli, Pawlowski 2004). Kendall's W takes on values between zero and one (Kendall, Gibbons 1990). The value of zero means that that there is no agreement between the experts, meaning that the achieved consensus is a matter of chance. The value of one represents full agreement between the experts, meaning that all of them have provided identical answers. Schmidt (1997) proposes that Kendal's $\mathrm{W}$ offers the best measure of agreement in the application of the Delphi method. According to him, $\mathrm{W}=0.5$ represents moderate agreement and a fair confidence in rankings, whereas $\mathrm{W}=0.7$ represents strong agreement and high confidence in rankings.

From the point of view of risk minimization, monitoring is the key project-management activity after the contract between the project owner and contractor is signed. This suggests that the relationship between the project owner's and contractor's project managers is therefore the key relationship at this stage of the project.

\section{Risk minimization: respondents' perceptions}

Before moving to the main findings, the results will be presented starting with the last section of the survey, in which the respondents were asked to list specific communication risks between the project parties, as well as to list most appropriate risk-minimization approaches in each case. The most important responses are presented in this section so as to give substance to the argument that follows. The majority of pertinent responses concerns the relationship between the project owner and contractor, on the one hand, and the project owner's and contractor's project managers, on the other. The latter relationship deserves special attention, as will be argued in the next section. So far, this relationship has not received sufficient notice from the research community concerned with the construction field.

Referring to communication in general, three respondents argue that all the relationships addressed in this survey would be much improved by "regular meetings" and "regular reporting", as well as a "greater flow of information" between project parties. As another respondent points out, the main message to project parties is that they should "communicate properly". These are important pointers for future research.

\subsection{Project owner-contractor}

This is the relationship between the principal and the agent. It is central to the principal-agent theory. However, the project managers surveyed have many critical comments about this relationship. According to one respondent, there is "no direct communication between the project owner and contractor because project managers act as buffers between parties; an appropriate communication protocol must be set up". Another respondent suggests that "all critical issues should be openly discussed 
without hidden agendas due to the very complex nature of the construction process". Yet another states that "the highest risk is the inability of the owner to clearly explain what is expected from the contractor - unclear scope definition, vague expectations, etc". Two respondents mention "incomplete progress reports" and "incomplete contract and design documents" as special problems. What is needed, according to one respondent, is "clear and consistent change-management from the project owner's side". Another points out that "there is almost no communication between the project owner and the contractor once the contract is signed". Yet another respondent argues that "the most important thing is to prepare detailed and understandable contracts". One respondent points out that both parties to the contract "should assess the previous experiences, financial ability, and capacity of the opposite side".

\subsection{Project owner-project owner's project manager}

This is the relationship between the principal and an agent hired by the principal to monitor another agent, the contractor. Again, the project managers surveyed report a number of problems regarding this relationship. One respondent states that there is a "lack of on-time reports". Another points out that "clear definitions of responsibilities" are needed. According to one respondent, it is essential that the project owner "clearly explains the goals of the project to its project manager in order to avoid confusions". Another states that "the project owner may fail to define the company's strategy to its project manager". One respondent mentions "unclear targets, sometimes close to "hidden agendas", from the project owner's side". Another states that "on-time updates regarding decisions by the project owner" are necessary. According to yet another respondent, "a long-term relationship between the project owner and its project manager should be preferred to better understand each other".

\subsection{Contractor-contractor's project manager}

In this case, the contractor acts as the principal in relation to the agent directly involved in a project. The relationship has its own difficulties. One respondent argues that "the project manager should be assigned from the core of organization, so that he/she would be in position to make better assessment concerning possible conflicts and guide the higher management". Another states that "the contractor's project manager cannot be successful without higher management support". According to one respondent, there is "a need for a well-established reporting system and regular site visits to ensure that the contractor's project manager is acting properly". Yet another respondent points out that "the contractor should have follow-up and reporting mechanisms, so as to avoid problems".

\subsection{Project owner's project manager-contractor's project manager}

The two agents, one working for the principal and another for the contractor as an agent, are in most direct relationship during a construction project, and especially in its monitoring phase. Most project managers surveyed consider this relationship crucial during construction itself. Six respondents state that "this relationship is the most important" after the contract is signed. According to one of them, "project owners and contractors usually have more than one project, so it is most important for their project managers to work together". Another respondent argues that "this relationship is the most subjective one". "Informal information flow" between the two project managers is stressed by yet another respondent. One respondent points out that "most projects fail on the personal level". According to one respondent, "the social relationship should extend outside of the project i.e. by means of their families". "Some social activities, such as company banquets, may be helpful in providing an informal atmosphere", states one respondent. Another one suggests that "both project managers should have the same level of authority; if this is not the case, the decision-making process can be negatively affected". According to yet another respondent, "the main risk is that the project owner asks for improvements regarding the project that he assumes are included in the project, but the contractor assumes that they should be paid for on top of the project".

\section{Main findings}

The exploratory survey concerned the relationships between pairs of four key project participants (Ceric 2012). It focused on the relationships in the upper part of the diagram shown in Figure 2. The means and standard deviations are used mainly as indicators of the relative importance of various relationships studied. The relative importance of these pairs in risk minimization after the contract is signed is shown below (Table 1).

In particular, the relationship between the two project managers was considered by the respondents to the exploratory survey to be most important for risk minimization. The results shown in the table below are those for the twenty practitioners of project management selected for further research. Throughout, the scale from 1 to 9 (where 9 is most important) is used to rate the importance of each relationship between project parties in terms of the communication risk involved.

Table 1 . The exploratory survey

\begin{tabular}{llcc}
\hline Rank & \multicolumn{1}{c}{ Relationship } & Mean & $\begin{array}{c}\text { St. } \\
\text { Dev. }\end{array}$ \\
\hline 1 & $\begin{array}{l}\text { Project owner's project manager } \rightarrow \\
\text { Contractor's project manager }\end{array}$ & 7.70 & 1.66 \\
\hline 2 & Project owner $\rightarrow$ Contractor & 7.30 & 1.63 \\
\hline 3 & $\begin{array}{l}\text { Project owner } \rightarrow \text { Project owner's } \\
\text { project manager }\end{array}$ & 6.90 & 1.65 \\
\hline 4 & $\begin{array}{l}\text { Contractor } \rightarrow \text { Contractor's project } \\
\text { manager }\end{array}$ & 6.74 & 1.66 \\
\hline
\end{tabular}


Table 2. Delphi round one

\begin{tabular}{lllc}
\hline Rank & \multicolumn{1}{c}{ Relationship } & Mean & $\begin{array}{c}\text { St. } \\
\text { Dev. }\end{array}$ \\
\hline 1 & $\begin{array}{l}\text { Contractor's project manager } \rightarrow \\
\text { Project owner's project manager }\end{array}$ & 8.39 & 0.74 \\
\hline 2 & $\begin{array}{l}\text { Project owner's project manager } \rightarrow \\
\text { Contractor's project manager }\end{array}$ & 8.00 & 1.96 \\
\hline 3 & $\begin{array}{l}\text { Project owner } \rightarrow \text { Project owner's } \\
\text { project manager }\end{array}$ & 7.07 & 1.14 \\
\hline 4 & $\begin{array}{l}\text { Project owner's project manager } \rightarrow \\
\text { Project owner }\end{array}$ & 6.61 & 1.30 \\
\hline 5 & Contractor $\rightarrow$ Project owner & 6.61 & 2.08 \\
\hline 6 & Project owner $\rightarrow$ Contractor & 6.57 & 2.21 \\
\hline 7 & $\begin{array}{l}\text { Contractor } \rightarrow \text { Contractor's project } \\
\text { manager }\end{array}$ & 6.43 & 1.22 \\
\hline 8 & $\begin{array}{l}\text { Contractor's project manager } \rightarrow \\
\text { Contractor }\end{array}$ & 6.39 & 1.27 \\
\hline
\end{tabular}

Round one of the Delphi method considers all relationships shown by arrows in Figure 2 (Table 2).

Several results are noteworthy. First, the relationship between the contractor's project manager and project owner's project manager come on top (8.39). The reverse relationship is not far behind (8.00), but it is also characterised by a relatively high standard deviation (1.96 as compared to 0.74 for the previous relationship). Second, the relationship between the project owner and project owner's project manager comes next in terms of risk minimization during the construction phase (7.07). The reverse relationship is some way behind in terms of relative importance (6.61). Third, it should be noted that the same score applies to the relationship between the contractor and project owner, but the standard deviation is considerably higher in the latter case (2.08 as compared to 1.30). The relationship between the project owner and contractor is close behind (6.57), but the standard deviation is even higher in this case (2.21). It is important to note that standard deviations are highest in the case of the relationship between the project owner and contractor, as well as that between the contractor and project owner (2.21 and 2.08). In other words, the disagreement between respondents is the highest in these two cases. Fourth, the relationship between the contractor and contractor's project manager, as well as the reverse relationship, come last in terms of importance in risk minimization (6.43 and 6.39). In these two cases, standard deviations are relatively low (1.22 and 1.27), thus suggesting relatively strong agreement between respondents.

Following the first Delphi round conducted in the research presented here, the obtained concordance coefficient $\mathrm{W}=0.319$ with the level of significance $\alpha \cdot<0.0001$. This represents a weak agreement between the experts, which necessitates another Delphi round.

Round Two of the Delphi method provides a wide range of mean scores (6.36-8.57), as well as a narrow range of standard deviations (0.63-1.18), which shows
Table 3. Delphi round two

\begin{tabular}{|c|c|c|c|}
\hline Rank & Relationship & Mean & $\begin{array}{l}\text { St. } \\
\text { Dev. }\end{array}$ \\
\hline 1 & $\begin{array}{l}\text { Project owner's project manager } \rightarrow \\
\text { Contractor's project manager }\end{array}$ & 8.57 & 0.65 \\
\hline 2 & $\begin{array}{l}\text { Contractor's project manager } \rightarrow \\
\text { Project owner's project manager }\end{array}$ & 8.46 & 0.63 \\
\hline 3 & $\begin{array}{l}\text { Project owner } \rightarrow \text { Project owner's } \\
\text { project manager }\end{array}$ & 7.07 & 1.07 \\
\hline 4 & Project owner $\rightarrow$ Contractor & 6.79 & 0.97 \\
\hline 5 & Contractor $\rightarrow$ Project owner & 6.71 & 0.99 \\
\hline 6 & $\begin{array}{l}\text { Project owner's project manager } \rightarrow \\
\text { Project owner }\end{array}$ & 6.61 & 1.18 \\
\hline 7 & $\begin{array}{l}\text { Contractor } \rightarrow \text { Contractor's project } \\
\text { manager }\end{array}$ & 6.57 & 1.16 \\
\hline 8 & $\begin{array}{l}\text { Contractor's project manager } \rightarrow \\
\text { Contractor }\end{array}$ & 6.36 & 1.15 \\
\hline
\end{tabular}

that a reasonable consensus between the respondents has been achieved (Table 3).

A number of important results follow. First, the relationship between the two project managers comes on top in terms of the scores. The means are considerably higher and standard deviations considerably lower than those concerning all other relationships between the key project partners. Although the relationship between the project owner's project manager and the contractor's project manager comes on top (8.57), the reverse relationship is not far behind (8.46). It can be concluded that both relationships are similar in terms of their importance in risk minimization in the construction phase of a project. Second, the relationship between the project owner and project owner's project manager comes next in terms of importance (7.07). However, the reverse relationship is considerably less important according to the respondents (6.61). A strong asymmetry can be noted here by comparison with all the other relationships considered in this research. Third, the relationship between the project owner and contractor, as well as the reverse relationship, come next in terms of importance in risk minimization (6.79 and 6.71). The scores suggest that these two relationships are of similar importance to project success. Fourth, the relationship between the contractor and contractor's project manager are considered by the respondents to be least important (6.57 and 6.36). Again, these relationships are quite similar in terms of their relative importance.

Following the second Delphi round, the obtained concordance coefficient $\mathrm{W}=0.430$ with the level of significance $\alpha \cdot<0.0001$. The Kendall's coefficient of concordance has increased by 35 percent, which shows that the agreement between the experts has also increased by the same percentage. Since the achieved value of $\mathrm{W}$ is considerably smaller than 0.7 , it is necessary to consider the need for the third Delphi round. The analysis was performed by using the non-parametric Spearman's 
rank correlation test (Siegel, Castellan 1988). The ordered relationships between participating experts in Delphi rounds one and two were correlated. Spearman's rank correlation coefficient rho $=0.905$ was calculated. A value so high indicates a strong interdependence of results achieved in the first and second Delphi round. In conclusion, the third Delphi round would be unlikely to change the rankings of the relationships between the respondents, as well as Kendall's coefficient of concordance. Therefore the third Delphi round was considered unnecessary.

As can be seen by comparing the results of the exploratory survey and two Delphi rounds as presented in Tables $1-3$, the importance of the project owner's and contractor's project managers grows in importance through the Delphi process. This can be seen through the growing mean values of the scores. Also, the consensus between the respondents grows through the process, as can be seen from the decreasing standard deviations in the scores. It is important to note that the two project managers exchange their places twice over the rounds, which demonstrates that monitoring is a two-way process. The two project managers as agents of the principal and the main agent - that is, the project owner and contractor dominate the construction process in terms of importance.

However, there is no contract between these two agents. As construction is a crucial stage of any project, this finding requires careful scrutiny in terms of the importance of agents in the principal-agent theoretical framework. In the case of construction, further theoretical development is needed to better understand the best approach to risk minimization in the monitoring process.

\section{Limitations}

The Delphi method is an appropriate tool for investigation of project managers' perceptions. According to Brauers (2003) there are two developments of Delphi method: one is based on meeting, and the other on questionnaires. The organization of a meeting produces quicker results. However, the meeting has to be organized in such a way that communication between the panel members is impossible. Nowadays teleconferences could be used to overcome geographical limitation of the experts. In this study the questionnaires were used for the application of the Delphi method. One of the limitations of this study is that the number of experts has decreased over time. In the first round, 15 out of 20 selected respondents participated (response rate: 75 percent). In the second and final Delphi round, 11 out of 15 respondents took part (response rate: 73 percent). Therefore, the tool can be used to provide a focus for further research rather than to arrive at definite results.

\section{Conclusions}

The research presented here offers new challenges for the principal-agent theory. In construction, the project owner is the principal and contractor is the agent. However, both of them have their own agents. The two project managers play key roles in the construction phase of every major project, when both the project owner and contractor play subsidiary roles on account of project complexity and duration. This is when project managers, although agents, play key roles in construction projects.

Although project managers may act cooperatively with their principals, they may also act opportunistically, as the principal-agent theory points out. Therefore, the theoretical framework needs to be extended to encompass the interaction between the key agents involved in construction projects, especially when there are no contracts between the agents. A better understanding of that interaction is likely to be of value to other fields in which project managers play key roles in the execution of complex projects.

The intricacies of the monitoring process, which is at the focus of the research presented here, will require much more detailed investigation of project managers and their interaction to arrive at the most promising interplay between formal and informal communication during construction. For instance, communication protocols defined in contracts may help improve the monitoring process. Such an investigation could be best achieved by means of interviews and/or focus groups. Many pointers for further study can be found in the above section outlining the respondents' perceptions. They offer a useful guidance for further research.

\section{Acknowledgments}

I would like to thank the anonymous referees for the helpful comments.

I very much appreciate the contribution of the respondents to the last two rounds of the survey: Stephen Burrows, Mete Demir, Ahmet Erol, Medhat Etman, Gulsah Fidan, Cihat Gurel, Sinisa Matic, Ferit Oncel Mocan, Baris Nazlim, Sinisa Radakovic, Wilhelm Reismann, Ophir Rozenfeld, Aydin Sakin, Gullem Sivecas Gibert, and Ertugrul Unluturk. I would like to thank them all.

Last, but not least, I would like to thank the Ministry of Science of the Republic of Croatia for the sponsorship of the five-year research project under my supervision entitled "Human resource management in construction projects" (Project code: 082-0822156-2998).

\section{References}

Brauers, W. K. 2003. Optimization method for a stakeholder society: a revolution in economic thinking by multi-objective optimization. New York: Kluwer Academic/Springer. 352 p.

Brauers, W. K. 2008. Group decision making with multiobjective optimization, Foundations of Computing and Decision Sciences 33(2): 167-179.

Brauers, W. K. 2012. Project management for a country with multiple objectives, Czech Economic Review 6: 80-101.

Ceric, A. 2003. A framework for process-driven risk management in construction projects: PhD Thesis. Research Institute for the Built \& Human Environment, School of Construction and Property Management, University of Salford. $284 \mathrm{p}$.

Ceric, A. 2012. The principal-agent theory and the role of project managers in construction: guidlines for future research, in 
Proceedings of Joint CIB International Symposium W055, W065, W089, W118, TG76, TG78, TG81, TG84: Research to Practice, 26-29 June 2012, Montreal, Canada.

Chan, A. P. C.; Yung, E. H. K.; Lam, P. T. I.; Tam, C. M.; Cheung, S. O. 2001. Application of Delphi method in selection of procurement systems for construction projects, Construction Management and Economics 19(7): 699-718. http://dx.doi.org/10.1080/01446190110066128

Chang, C. Y.; Ive, G. 2007. The hold-up problem in the management of construction projects: a case study of the channel tunnel, International Journal of Project Management 25(4): 394-404.

http://dx.doi.org/10.1016/j.ijproman.2007.01.001

Corvellec, H.; Macheridis, N. 2010. The moral responsibilities of project selectors, International Journal of Project Management 28(3): 212-219.

http://dx.doi.org/10.1016/j.ijproman.2009.05.004

Delbecq, A. L.; Van de Ven, A. H.; Gustafsson, D. H. 1975. Group techniques for program planning: a guide to nominal group and Delphi processes. Illinois: Scott-Foresman and Co. $174 \mathrm{p}$.

Eisenhardt, M. K. 1989. Agency theory: an assessment and review, Academy of Management Review 14(1): 57-75. http://dx.doi.org/10.2307/258191

Ericsson, S.; Henricsson, J. P. E. 2005. Deconstructing construction competitiveness - the initial results of a Delphi survey in Finland, Sweden and the UK, in Proceedings of Construction and Building Research (COBRA) Conference, 4-8 July 2005, Brisbane, Australia.

Hendrickson, C.; Au, T. 1989. Project management for construction: fundamental concepts for owners, engineers, architects, and builders. Pittsburg: Prentice Hall. 496 p.

Holt, G. D.; Olomolaiye, P. O.; Harris, F. C. 1995. A review of contractor selection practice in the U.K. construction industry, Building and Environment 30(4): 553-561. http://dx.doi.org/10.1016/0360-1323(95)00008-T

Hsu, C. C.; Sandford, B. A. 2007. The Delphi technique: making sense of consensus, Practical Assessment, Research \& Evaluation 12(10): 1-8.

Huang, C. F.; Hsueh, S. L. 2010. Customer behavior and decision making in the refurbishment industry-a data mining approach, Journal of Civil Engineering and Management 16(1): 75-84.

http://dx.doi.org/10.3846/jcem.2010.07

Ive, G.; Chang, C. Y. 2007. the principle of inconsistent trinity in the selection of procurement systems, Construction Management and Economics 25(7): 677-690. http://dx.doi.org/10.1080/01446190601164089

Jäger, C. 2008. The principal-agent theory within the context of economic sciences. Norderstedt: Books on Demand GmbH. 60 p.

Jensen, M. C. 2000. The theory of the firm: governance, residual claims, and organizational forms. Cambridge: Harvard University Press. 323 p.

Kendall, M. G.; Gibbons, J. D. 1990. Rank correlation methods. London: Edward Arnold. 260 p.

Knapp, T. R. 1990. Treating ordinal scales as interval scales: an attempt to resolve the controversy, Nursing Research 39(2): 121-123. http://dx.doi.org/10.1097/00006199-199003000-00019

Kolltveit, B. J.; Grønhaug, K. 2004. The importance of the early phase: the case of construction and building projects, International Journal of Project Management 22(7): 545-551. http://dx.doi.org/10.1016/j.ijproman.2004.03.002

Lindeman, C. A. 1975. Delphi-Survey of Priorities in Clinical Nursing Research, Nursing Research 24(6): 434-441. http://dx.doi.org/10.1097/00006199-197511000-00006

Linstone, H. A.; Turoff, M. 1975. The Delphi method: techniques and applications. Michigan: Addison-Wesley. $621 \mathrm{p}$.
Müller, R.; Turner, J. R. 2005. The impact of principal-agent relationship and contract type on communication between project owner and manager, International Journal of Project Management 23(5): 398-403.

http://dx.doi.org/10.1016/j.ijproman.2005.03.001

Okoli, C.; Pawlowski, S. D. 2004. The Delphi method as a research tool: an example, design considerations and applications, Information \& Management 42(1): 15-29. http://dx.doi.org/10.1016/j.im.2003.11.002

Park, M.; Lee, H. S.; Kwon, S. 2010. Construction knowledge evaluation using expert index, Journal of Civil Engineering and Management 16(3): 401-411. http://dx.doi.org/10.3846/jcem.2010.46

Project Management Institute 2009. A Guide to the project management body of knowledge. 4th edition. Project Management Institute. $459 \mathrm{p}$.

Rosenfeld, Y.; Geltner, D. 1991. Cost-plus and incentive contracting: some false benefits and inherent drawbacks, Construction Management and Economics 9(5): 481-490. http://dx.doi.org/10.1080/01446199100000036

Schieg, M. 2008. Strategies for avoiding asymmetric information in construction project management, Journal of Business Economics and Management 9(1): 47-51. http://dx.doi.org/10.3846/1611-1699.2008.9.47-51

Schmidt, R. C. 1997. Managing Delphi surveys using nonparametric statistical techniques, Decision Sciences 28(3): 763-774.

http://dx.doi.org/10.1111/j.1540-5915.1997.tb01330.x

Sharkey, S. B.; Sharples, A. Y. 2001. An approach to consensus building using the Delphi technique: developing a learning resource in mental health, Nurse Education Today 21(5): 398-408. http://dx.doi.org/10.1054/nedt.2001.0573

Siegel, S.; Castellan, N. 1988. Nonparametric statistics for the behavioural sciences. Michigan: McGraw-Hill. 399 p.

Stevens, S. S. 1946. On the theory of scales of measurement, Science 103(2684): 677-680. http://dx.doi.org/10.1126/science.103.2684.677

Tadelis, S. 2002. Complexity, flexibility, and the make-or-buy decision, American Economic Review 92(2): 433-437. http://dx.doi.org/10.1257/000282802320191750

Turner, R.; Müller, R. 2004. Communication and co-operation on projects between the project owner as principal and the project manager as agent, European Management Journal 22(3): 327-336. http://dx.doi.org/10.1016/j.emj.2004.04.010

Unsal, H. I.; Taylor, J. E. 2010. Modelling inter-firm dependency: a game-theoretic simulation to examine the hold-up problem in project networks, ASCE Journal of Construction Engineering and Management 137(4): 284-293. http://dx.doi.org/10.1061/(ASCE)CO.1943-7862.0000286

Winch, G. 2002. Managing construction projects. New Jersey: Blackwell Science. 485 p.

Yiu, C. Y.; Lo, S. M.; Ng, S. T.; Ng, M. M. F. 2002. Contractor selection for small building works in Hong Kong, Structural Survey 20(4): 129-135.

http://dx.doi.org/10.1108/02630800210445690

Yousuf, M. I. 2007. Using experts' opinion through Delphi technique, Practical Assessment, Research \& Evaluation 12(4): 1 .

Zavadskas, E. K.; Turskis, Z.; Tamošaitiene, J. 2010. Risk assessment of construction projects, Journal of Civil Engineering and Management 16(1): 33-46. http://dx.doi.org/10.3846/jcem.2010.03

Zavadskas, E. K.; Vilutiene, T.; Turskis, Z.; Tamosaitiene, J. 2010. Contractor selection for construction works by applying SAW-G and topsis grey techniques, Journal of Business Economics and Management 11(1): 34-55. http://dx.doi.org/10.3846/jbem.2010.03 


\section{Appendix A}

\section{First Delphi Round}

\section{SURVEY QUESTIONNAIRE}

\section{Communication risks in construction projects - introduction}

This research concerns the relationship between the project owner, contractor, and their project managers (Fig. 2).

These four parties are crucial to the success of every project. This research focuses on risks associated with their communication. The focus here is on information asymmetry in the project-management process. An example of information asymmetry is when one party does not fully know what the other knows or does.

This survey follows upon the exploratory survey. Twenty practitioners of project management have been selected for the two rounds. Both in terms of years of experience and of project size managed, they can be considered experts in the field.

The exploratory survey concerned the relationships between pairs of four key project participants. It focused on the relationships in the upper part of the diagram above. The relative importance of these pairs in risk minimization after the contract is signed is shown in the table below. In particular, the relationship between the two project managers was considered by the respondents to the previous survey to be most important for risk minimization. The results shown in the table below are those for the twenty practitioners of project management selected for further research.

Note that the means represent the level of importance on the scale from 1 to 9 (where 9 is "most important"). Also note that all standard deviations between the twenty respondents selected for further research were quite low and uniform across the four pairs. That means that there was little disagreement between the respondents.

\section{SURVEY QUESTIONS}

\section{A. General information}

Note that personal information will remain private.

Name:

\section{B. Risk minimization - Relative importance of relationships between project parties}

In this round of the research all relationships between the four key parties to a project are considered. These are shown on both upper and lower sides of the diagram above. This involves all relationships between all parties involved.

Note that information asymmetry changes once the contracts between different parties involved in a project are signed. Only three contracts are involved in the process. These are contracts between the project owner and contractor, as well as contracts between them and their project managers. Also note that only eight relationships are considered here. They are shown in the diagram above by eight arrows. Self-interest is also not considered here. The relationships which are not considered are to be left blank in the boxes of the table below.

Please use the scale from 1 to 9 (where 9 is "most important") to rate the importance of each relationship between project parties in terms of communication risk involved:

\begin{tabular}{|c|c|c|c|c|c|}
\hline Survey question/Relationship & & $\mathrm{PO} \rightarrow \mathrm{C}$ & $\mathrm{PO} \rightarrow \mathrm{PMpo}$ & $\mathrm{C} \rightarrow \mathrm{PMc}$ & $\mathrm{PMpo} \rightarrow$ PMc \\
\hline \multirow{2}{*}{$\begin{array}{l}\text { Gathering information after } \\
\text { contract is signed between } \\
\text { parties }\end{array}$} & Mean & 7.30 & 6.90 & 6.74 & 7.70 \\
\hline & St. Dev. & 1.63 & 1.65 & 1.66 & 1.66 \\
\hline From (row) $\rightarrow$ To (column) & \multicolumn{2}{|c|}{$\mathrm{PO}$} & PMpo & PMc & $\mathrm{C}$ \\
\hline$\overline{\mathrm{PO}}$ & \multicolumn{2}{|c|}{ Leave blank } & \multicolumn{3}{|c|}{ Leave blank } \\
\hline PMpo & & Leave blank & & \multirow[t]{2}{*}{ Leave blank } \\
\hline PMc & \multicolumn{2}{|c|}{ Leave blank } & \multicolumn{2}{|r|}{ Leave blank } & \\
\hline $\mathrm{C}$ & & & Leave blank & & Leave blank \\
\hline
\end{tabular}




\section{Appendix B}

\section{Second Delphi Round}

\section{SURVEY QUESTIONNAIRE}

\section{Communication risks in construction projects - introduction}

The aim of this survey is to reach a consensus between project-management experts on the most important relationships between the key project parties in terms of risk minimization in the construction phase of the project, after the contract is signed.

The results of the previous Delphi round are shown in the table below. This is the state of consensus at present stage. Both means or averages and standard deviations are shown, where standard deviations show mean or average deviations from means. The smaller they are, the greater the agreement.

\section{SURVEY QUESTIONS}

\section{A. General information}

Note that personal information will remain private.

Name:

\section{B. Risk minimization - Relative importance of relationships between project parties}

Having seen the results of the previous round, or the consensus between experts at present stage, you may wish to reconsider your previous responses. But this is by no means required. However, if you do wish to modify your previous responses, use the table below.

Please use the scale from 1 to 9 (where 9 is "most important") to rate the importance of each relationship between project parties in terms of communication risk involved:

\section{Communication risk minimization}

Please list specific communication risks between the project parties that you consider most important for project success after the contract is signed. If possible, also list most appropriate risk-minimization approaches in each case.

Project owner $\rightarrow$ Contractor:

Contractor $\rightarrow$ Project owner:

Project owner $\rightarrow$ Project owner's project manager:

Project owner's project manager $\rightarrow$ Project owner:

Contractor $\rightarrow$ Contractor's project manager:

Contractor's project manager $\rightarrow$ Contractor:

Project owner's project manager $\rightarrow$ Contractor's project manager:

Contractor's project manager $\rightarrow$ Project owner's project manager.

\begin{tabular}{llcccc}
\hline \multicolumn{2}{l}{ From (row) $\rightarrow$ To (column) } & PO & PMpo & PMc & C \\
\hline \multirow{2}{*}{ PO } & Mean & & 7.07 & & 6.57 \\
& St. Dev. & & 1.14 & & 2.21 \\
\hline \multirow{2}{*}{ PMpo } & Mean & 6.61 & & 8.00 & \\
& St. Dev. & 1.30 & & 1.96 & \\
\hline \multirow{2}{*}{ PMc } & Mean & & 8.39 & & 6.39 \\
& St. Dev. & & 0.74 & & 1.27 \\
\hline \multirow{2}{*}{$\mathrm{C}$} & Mean & 6.61 & & 6.43 & \\
& St. Dev. & 2.08 & & 1.22 & \\
\hline
\end{tabular}

\begin{tabular}{lcccc}
\hline From (row) $\rightarrow$ To (column) & PO & PMpo & PMc & C \\
\hline PO & Leave blank & & Leave blank & \\
\hline PMpo & & Leave blank & & Leave blank \\
\hline PMc & Leave blank & & Leave blank & \\
\hline C & & Leave blank & & Leave blank \\
\hline
\end{tabular}

Anita CERIC. She is a Professor at the Department of Construction Management and Economics at the Faculty of Civil Engineering at the University of Zagreb. She was awarded her M.Sc. in Civil Engineering at the same University and she received her PhD. from the School of Construction and Property Management at the University of Salford, United Kingdom. Her research interests are in risk management, human resource management, and maintenance management. She is a member of W55 Working Commission on Building Economics and W65 Working Commission on Construction Management of the International Building Council (CIB); International Project Management Association (IPMA); Engineering Project Organizations Society (EPOS); ASCE (American Society of Civil Engineers) and AOM (Academy of Management). Currently, she is the Vice-Dean for International Collaboration at the Faculty of Civil Engineering at the University of Zagreb. 